\title{
REALIZATION OF THE CATEGORY OF ABSTRACT IN A FICTIONAL TEXT. LEXICAL, SEMANTIC AND DERIVATIONAL DIMENSIONS
}

\author{
Tamara Goli-Oglu \\ $\mathrm{PhD}$ in Philology, Associate Professor, Head of the Department of Ukrainian Language \\ and Slavic Philology, Pryazovskij State Technical University, Ukraine \\ e-mail: goli.oglu.t.v@gmail.com,orcid.org/0000-0002-7474-2563
}

\section{Liudmyla Borodenko}

PhD in Philology, Assistant Professor at the Department of Ukrainian Language and Slavic Philology, Pryazovskyi State Technical University, Ukraine e-mail: lusi11271@gmail.com,orcid.org/0000-0002-4409-8615

\section{Summary}

The article represents investigation of the problem defining the essence of the category of abstract and its correlation with the category of concrete in language. The specified problem has many aspects, it being on the edge of linguistics, philosophy and logics. The analysis of abstract vocabulary in M. Bulgakov's novel "Master and Margarita" was carried out in lexical and semantic and derivational dimensions at synchronistical level with application of the corresponding methods of analysis, elements of statistical analysis were used for guaranteeing greater precision of the results achieved.

In the research process it was revealed that the biggest group, were abstract nouns with the meaning of emotional and psychological state, their number being nearly one third of the total number of analyzed units. The level of nouns' abstractness correlates with the numerical data, the bigger the level of abstractness is, the bigger in size is the lexical-semantic group.

Our derivational analysis demonstrated this regularity, as the greater part of abstract nouns in "Master and Margarita" novel, by M. Bulgakov were created by methods of suffixation and zero-affixation methods, the lexical units, belonging to "psychological and emotional state" and "process and action" group form the biggest share, while the smallest part belongs to the group, denoting estimation of measure and degree, manifestation of signs or degree of intensity of a process.

Keywords: abstract lexica, abstract nouns, denotational and significational meaning, typological analysis, artistic text.

\section{DOI: https://doi.org/10.23856/3842}

\section{Introduction}

The problem of defining the essence of the category of abstract and its relation to the category of concrete has attracted the attention of scholars for many a century. The specified problem has many aspects, it being on the edge of linguistics, philosophy and logics. It acquires some special topicality at the period of nowadays formation of linguistic thought, for which an inter-discipline approach to the analysis of language factors is typical, it being characterized by syncretic scientific search and, hence, to its results.

The process of abstracting is unstoppable and continuous in speech and language activity of any human group, as man's thought is simultaneously strongly attracted by both concretization, i.e. by clear formation of thoughts and by generalization, systematization of observations, things, happening ion outward reality, and that is what is called abstracting. 
So, abstracting is detachment of the signs essential in a current speech situation for an object or phenomenon, abandoning not important signs, this is one of means of realization of cognitive action of a nation. The results of such activity are implemented in abstract lexica of literary language.

Abstract lexica was the object of investigation for such prominent Ukrainian linguistics, like O. O. Potebnya, I. I. Kovalyk, V. V. Nimchuk, L. M. Polyuga, I. P. Chepiga, V. O. Shadura, I. Lekov, V. V. Veselitskyi, R. M. Tseytlin - Russian scholars; V. Stashaytene from Lithuania, though their investigations are diachronic being based on historic language material. However, we are firmly convinced that the analysis of abstract vocabulary in lexical, semantic and derivational dimensions would be topical at synchronic level, as in this case not only semantic description of the units of this layer would be done, but a detailed analysis of their structure and derivation as well.

The nature of the category of abstract is unstable, changeable as the boundary between abstractness and concreteness is sometimes not clear and can be undermined at the logical and philosophic level and it is expressed in the language system, so, transitions from concrete to abstract are possible in it.

The category of abstract is mostly realized numerically in nouns. Abstract nouns are an essential lexical layer, in terms of their number, of any language, peculiarities of their semantics become apparent only in correlation with the concrete. Semantics of abstract nouns is very wide and diversified, it specifies complex and polyvectorial character of its analysis. So, we believe that it would be advisable to analyze it on the material of a concrete work "Master and Margarita", as it has not bee yet an object of scientific lexical and derivational search, it making our research topical.

\section{The category of the abstract in modern linguistics}

As it is known, the category of abstractness/concreteness is revealed in cognition in generalizations and comprehension. In philosophical sense concrete is something real, material, something that can be sensed by human, it is a thing or a group of things (material objects), whilst abstract is something existing alongside with the concrete, but devoid of material covering and thus devoid of opportunity of being sensed.

Scientific abstraction makes it possible to conceive language regularities, language categories and language paradigms, elements of a word, word combinations and texts. All these is an example of abstract in linguistics and it differs from philosophic interpretation of abstract

As it is known from scientific sources, abstract vocabulary:

"is a part of lexical and semantic language system, embracing units, that denote notions, which have no actual realization, so they express state, process, feeling, quality, personal traits, various revelations of person's intellectual level, relationship between persons or nations, notions of etiquette, scientific and industrial terms and the like" (Rusanivskij, Taranenko, 2000: 134).

So, we can see that abstract vocabulary has no functional limitations, although, as a rule, only abstract nouns are counted as belonging to this category, as they possess grammar expression of the category of abstractness, particularly their own word-building suffixes, the bulk of it has no plural forms and cannot be combined with cardinal numerals (the so-called limited valency.

Some scholars propose to consider the character of link of denotational and significational meanings within a single lexical unit to a reason for dividing lexical units into concrete and abstract. The words, in which denotational and significational meaning prevail are included 
into the segment of concrete vocabulary, while the words in which significational or significational-denotational type of meaning prevail into abstract.

Nominations of subject signs, properties, actions, states, taken in complete abstracting from the bearers of these signs are considered to be abstract nouns, as well as nominations of generic notions, known as intellectual categories and also various scientific terminological nominations (Shmelyov, 1973).

As abstract nouns belong to lexical and semantic system of language, they are characterized by a series of signs, common for the entire lexical system: 1) they are specified by extra-linguistic factors, nominating actual objects and actions, signs of the objects of the surrounding reality; 2) they are prone to extra-linguistic alternations, which are instantly fixed into their semantics; 3 ) they have semantic and formal links with other words of the lexical system; 4) within the micro-system of their own they can strike a semantic relationship, particularly, synonymic, antonymic, homonymic, or paronymic.

Abstract vocabulary having no clear semantic structure it causes some difficulties for its investigation. It was pointed out in L. Polyuga's investigation that semantic structure of an abstract noun could be very wide and not underlined (Полюга, 1991). While defining semantics of such a unit it is necessary to by guided first and foremost by the context of its functioning and only after that by etymology, dialectology and resort to other methods of linguistic investigation. Such approach makes it possible to define quite clearly the meaning of an abstract unit, although it complicates the process of investigating the language material.

Fuzziness between semantic groups and lexical units also complicate the work, aimed at performing a semantic classification of these units. Abstract nouns are characterized by a series of lexical and semantic signs, they acting as their differentiating markers: 1) they denote only general, non-material phenomena, incapable of being visualized (words like humor, respect or motion); 2) they denote properties, feelings, that cannot be counted or can't undergo any quantitative measurement (competition, generosity, compassion); 3) denote notions, that a person can cognize by thinking only (acceleration, conception); 4) denote customs or events (baptism, name day, Eucharist).

Besides, abstract nouns possess specific grammar markers, particularly: 1) absence of relative number forms (the greater part of them are used in singular number only: (patience, sorrow, smartness; very few of them are used only in plural form). 2) inability to be combined with cardinal numbers (only some of them can be used with words like much or many); 3 ) the bulk of such nouns are unable of creating forms of subjective estimation.

So, abstraction is a part of the process of human thinking, taking part in formation of notions, that we pass with the help of sounds. This category is defined by its opposition to concrete, at the same time it correlating relationship, i.e. equal correlation.

\section{Lexical and semantic characteristics of abstract nouns of M. Bulgakov's novel "Master and Margarita"}

Lexical and semantic groups of abstract nouns, selected from Mikhail Bulgakov's novel "Master and Margarita" were compiled and characterized in the process of investigating of the research problem (table 1$)$.

So, we can see from the statistics that the biggest group belongs to the nouns, denoting "character's emotional and psychological state", there are 353 of them $(29,42 \%)$. The nouns, that belong to this group denote human emotions, feelings or mood. M. Bulgakov used the abovementioned nouns with the objective of more precise and colourful expression of emotional 
state of the novel's characters: «Закрыв глаза, она отдала лицьо ветру и думала с какой-то грустью о покинутом ею неизвестном береге реки... Рюхин пытался было их собрать, но, прошипев почему-то со злобой: "Да ну их к черту!...»» (Bulgakov, 1984: 574). Such nouns possess quite a high degree of abstraction, as feelings and emotons are but human's reaction to external irritating factors and the entire outward environment, incarnated into a verbal form, by means of words with abstract meaning. Psychologists singled out the main types of emotional reactions - emotional tone, situational emotion, affect, passion, mood and feeling. As we can see, all these notions belong to the domain of abstraction; only they are the basis for creation of abstracted part of the picture of the surrounding world. Confirmation of this can be found in psychology, particularly, A. N. Leontyev thought that "passionate expression of the world is one of essential signs of human cognition" (Leontev, 1965: 87).

Table 1

The results typological analysis are summarized in the table below

\begin{tabular}{|c|c|c|c|c|}
\hline № & Lexical-semantic group & $\begin{array}{c}\text { Number } \\
\text { of words (units) }\end{array}$ & $\begin{array}{c}\text { Words number } \\
(\%)\end{array}$ & Examples (Russian) \\
\hline 1 & $\begin{array}{l}\text { Character's emotional and } \\
\text { psychological state }\end{array}$ & 353 & 29,42 & $\begin{array}{c}\text { страх, любовь, гнев, } \\
\text { восторг }\end{array}$ \\
\hline 2 & Action, process & 215 & 17,92 & $\begin{array}{l}\text { рев, шорох, гул, } \\
\text { стук, звон }\end{array}$ \\
\hline 3 & Physical state & 159 & 13,25 & $\begin{array}{c}\text { полусон, } \\
\text { напряжение, } \\
\text { одиночество }\end{array}$ \\
\hline 4 & $\begin{array}{l}\text { Objects of subjective } \\
\text { evaluation }\end{array}$ & 139 & 11,57 & $\begin{array}{c}\text { справедливость, } \\
\text { правда, ложь }\end{array}$ \\
\hline 5 & $\begin{array}{l}\text { Behaviour, revelation of } \\
\text { personal traits }\end{array}$ & 128 & 10,67 & $\begin{array}{c}\text { решимость, } \\
\text { хамство, бдерзость, } \\
\text { достоинство }\end{array}$ \\
\hline 6 & External and internal signs & 126 & 10,5 & $\begin{array}{c}\text { зелень, тишина, } \\
\text { желтизна }\end{array}$ \\
\hline 7 & $\begin{array}{l}\text { Dimension or degree } \\
\text { of a sign }\end{array}$ & 49 & 4,08 & $\begin{array}{c}\text { глубина, вышина, } \\
\text { гущза, необъятность }\end{array}$ \\
\hline 8 & Circumstances, situations & 17 & 1,42 & $\begin{array}{c}\text { чрезвычайность, } \\
\text { беда }\end{array}$ \\
\hline 9 & $\begin{array}{l}\text { Realities and notions, } \\
\text { existing in the society }\end{array}$ & 14 & 1,17 & $\begin{array}{c}\text { власть, репутаичия, } \\
\text { деньги }\end{array}$ \\
\hline & On aggregate & 1200 & 100 & \\
\hline
\end{tabular}

Abstract nouns, that denote process are quite numerous in M. Bulgakov's novel "Master and Margarita" Examples in Russian: «Коровьев понравился Маргарите, и трескучая его болтовня подействовала на нее успокоительно...» (Bulgakov, 1984: 576). Numerical index of this group -215 units $(17,92 \%)$. The level of abstractness of the units belonging to this group is lower, as compared to the previous group, because the bulk of processes can be sensed and can lead to material results.

As fiction text is a clot of a life situation or situations of the entire spectrum of depicted problems the lexical-semantic group denoting "human physical state" is quite numerous, Examples in Russian: «Усталости она не чувствовала, и только пот тек по ней ручьями... 
Горячая, как лава, жижа обжигала руки, но Маргарита, не морщась, стараясь не причинить боли, втирала ее в колено» (Bulgakov, 1984: 568). The number of words in this group is 159 units $(13,25 \%)$. It should be noted that in M. Bulgakov's novel the number of abstract nouns, that express psychological state of characters is twice bigger than those, denoting physical/physiological state. We believe that this statistical fact demonstrates the general psychological-activity tendency of the novel, laid upon mystical foundation.

Another lexical-semantic group belongs to the nouns, expressing subjective estimation (Examples in Russian: «И не водою из Соломонова пруда, как хотел я для вашей пользы, напою я тогда Ершалаим!... В городе в это время возникали и распльвались совершенно невозможные слухи, в которых крошечная доля правды была изукрашена пышнейшим враньем» (Bulgakov, 1984: 366, 667-668). The numerical share of this group in the novel "Master and Margarita", by M. Bulgakov (11,57\%). Subjectivity of perception of the surrounding reality is typical not only for the main characters of the novel, but for the writer too. Subjective way of perception of the world is realized just in abstract nouns of axiological (estimating) modality.

The abstract nouns, expressing behaviour or revelation of attitude to persons (Examples in Russian: «Прикрепленный к новому жилищу насильственно, Иван едва руками не всплеснул от развязности женщинны и молча ткнул пальцем в пижаму из пунцовой байки... Но и падая, сохранил на окаймленном небольшими бакенбардами лице ульбку восторга и преданности» (Bulgakov, 1984: 414). and units with abstract meaning describing outward or inner signs of an object or phenomenon or situations are numerically equal in the novel "Master and Margarita", by M. Bulgakov (Examples in Russian: «Он вырисовался до последнего дерева под небом, расчистившимся до прежней полной голубизны, а река успокоилась... Вторая свежесть - вот что вздор!» (Bulgakov, 1984: 533). Such abstract nouns are almost equal numerically: 128 units $(10,67 \%)$ and 126 units $(10,5 \%)$ respectively. By using these words the author helps the reader plunge into the plot and conceive it in details, i.e. visualize it. As the units of these two groups express visual manifestation of abstract notions, that can be perceived with eye-sight, the level of abstractness of these nouns is much lower than the level of previously depicted lexical and semantic groups. So, the units of these two groups demonstrate some vagueness, "fuzziness" between the boundaries between abstract and concrete in language.

Abstract nouns, expressing degree/measure/intensity of revelation of a sign or an action have quite negligent numerical indices in the novel (examples in Russian: глубина, вылина, гуща,необъятность; 49 words / 4,08\%); those, expressing situations, into which M. Bulgakov's characters happen to be in the novel (Russian examples: чрезвычайность, беда, недоразумение, совпадение; 17 words / 1,42\%); social notions and realities of the Soviet social life of the first half of the XX century (examples in Russian: власть, репутация, деньги, слава, популярность; 14 words / 1.17\%). So, we can see that lexical-semantic group, expressing social signs is the smallest in number. And this is hardly strange, as the author of "Master and Margarita" paid attention mostly to philosophic problems, that are mystified in the novel to a certain extent, as well as to description of emotional and physical state of his characters, who had to exist in the absurd world of the Soviet reality. It's the social realities that act as an absurd background, some "alien" space. Inside the lexical and semantic groups of abstract nouns we sometimes can observe formation of synonymic (удовольствие - наслаждение, покой-равнодушие) or antonymic (злость - равнодушие, покой - возбуждение, жизнь смерть) words rows of mainly contextual character. We admit that the author applies to abstract antonyms as an stylistic device for expressing collision of contrast notions, that extend their semantics within the context. 


\section{Derivational characteristics of abstract nouns in M. Bulgakov's novel "Master and Margarita"}

Having analyzed abstract nouns in the novel "Master and Margarita", by M. Bulgakov in the lexical and semantic aspects we, now, can proceed to its derivational history.

In further analysis, the nouns with abstract meaning, that we had previously registered, as being 1200 in number, were divided into groups, according to the methods of word-formation and the type of word-forming formant. Derivational analysis is accompanied with morphological characteristic of motivating foundations of the abstract nouns, in which transparent inner shape of these units found its reflection (see table 2).

With regard to the results of the concluded investigation of the derivational nature of abstract nouns in the novel "Master and Margarita", by M. Bulgakov we may conclude that the fact that suffixation is the most productive method of derivation of these units, as cases of suffixation embrace $53.83 \%$ (646 words), it being more than half of the total number of registered units.

The words, coined by means of this suffix belong to different lexical-semantic groups. The meaning of emotional state is typical for more than half of registered words, their number is $-56.6 \%$ (Russian e.g. изумл-ен-ие, восхищ-ен-ие, волн-ен-ие, недоум-ен-ие), while $23.3 \%$ - are nouns bearing the meaning of process (Russian e.g. представление, разоблачен-ие, томл-ен-ие, наступл-ен-ие). Behaviour and attitude towards the surrounding world describe only $10.7 \%$ of analyzed nouns (Russian e.g. опас-ен-ие, сомн-ен-ие, ум-ен-ие). Only $9.4 \%$ of abstract nouns of this group characterize the meaning of physical state, circumstances and objects of subjective evaluation (Russian e.g. опьян-ен-ие, напряж-ен-ие, муч-ен-ие, осложн-ен-ие).

Among the analyzed nouns 122 were built by means of -ocmb suffix, it being $10.17 \%$ of their total number. All of them were motivated by participle base, despite their belonging to different lexical-semantic groups: 1) manifestation of attitude or behavior $-41.8 \%$ of words (Russian e.g. понятлив-ость, враждебн-ость, разговорчив-ость, бережн-ость); 2) emotional state $-17.2 \%$ (Russian e.g. нежн-ость, безнадежн-ость, рад-ость); 3) sign or peculiarity of an object or phenomenon - $15.6 \%$ (Russian e.g. странн-ость, бледн-ость, слаб-ость, редкость); 4) the meaning of subjective evaluation $-8.2 \%$ (Russian e.g. нелеn-ость, глуп-ость, справедлив-ость, мерз-ость); 5) physical state - $7.4 \%$ (Russian e.g. cblp-ocmb, устал-ость, неподвижн-ость); 6) expression of degree or degree - 5.7 \% (Russian e.g. близ-ость, необъятность); 7) circumstances of social signs - $4.1 \%$ (Russian e.g. случайн-ость, трудн-ость).

The rest of registered suffixes (see Table 2 ) have sufficiently smaller productivity Russian e.g: -ан(ие) (59 words / 4.92\%; молч-ан-ие, наказ-ан-ие, содрог-ан-ие, миг-ан-ие, изебет-ан-ие, страд-ан-ие, негодов-ан-ие, сострад-ан-ие, вним-ан-ие, созн-ан-ие, очертан-ие); -от(а) (46 слів / 3,83\%; рос. добр-от- , дуx-от- $а$, темн-от- $а$, дрем-от- , чистот- $a$, тошн-от- $а$, красота); -ств(о) (36 слів / 3\%; рос. волшеб-ство-, бешен-ство-, беспокой-ство-, хам-ство-, лукав-ство-, колдов-ство-).

The following suffixation formants demonstrate the lowest productivity at derivation in the novel "Master and Margarita" by M. Bulgakov: Russian e.g. $-H(a),-H(u),-\mu(u е)$ (poc. безд- $-a$, россказ-н-и, отчая-н-ие, раская-н-ие); -б(а) (рос. зло-б-а, борь-б-а, моль-б-а); -ин(а) (рос. глуб-ин-а, тии-ин-а, выии-ин-а); -есть (рос. свеж-есть-, прел-есть-, тяж-есть-); -ов(ь) (рос. люб-ов-ь);-ок (рос. беспоряд-ок-, рассуд-ок-, холод-ок-, недостат-ок-);-к- (рос. дым$\kappa-а$, блес-к-, придир-к-а, задерж-к-а, опас-к-а); -иц(а) (бессонн-иц- $а$, путан-ии- $а) ;-а н(ь е)$, -ен(ве) (рос. вр-ан-ье, ум-ен-ье). 
Table 2

Transparent inner shape of these units found its reflection

\begin{tabular}{|c|c|c|c|c|c|}
\hline \multirow{2}{*}{$\begin{array}{c}\text { Method of } \\
\text { derivation/formant }\end{array}$} & \multirow{2}{*}{$\begin{array}{c}\text { Number of } \\
\text { words/units }\end{array}$} & \multirow{2}{*}{$\begin{array}{l}\text { Number of } \\
\text { words }(\%)\end{array}$} & \multicolumn{3}{|c|}{ Motivating foundation } \\
\hline & & & Verbs & & \\
\hline $\begin{array}{l}\text { Having no affixes / } \\
\text { zero affixes } 0\end{array}$ & 432 & $36 \%$ & 190 & $\begin{array}{l}\text { Having no affixes / } \\
\text { zero affixes } 0\end{array}$ & 432 \\
\hline Suffixation /-ен(ие) & 159 & $13,25 \%$ & 158 & Suffixation /-ен(ие) & 159 \\
\hline Suffixation /-ость & 122 & $10,17 \%$ & - & Suffixation /-ость & 122 \\
\hline Suffixation /-ан(ие) & 59 & $4,92 \%$ & 59 & Suffixation /-ан(ие) & 59 \\
\hline Suffixation /-от(a) & 46 & $3,83 \%$ & 8 & Suffixation /-от(a) & 46 \\
\hline Suffixation /-ств(о) & 36 & $3 \%$ & 10 & Suffixation /-ств(o) & 36 \\
\hline $\begin{array}{l}\text { Suffixation /-н(a), } \\
- \text {-н(и), -н(ие) }\end{array}$ & 17 & $1,42 \%$ & 9 & $\begin{array}{l}\text { Suffixation /-н(a), } \\
-\mathrm{H}(и),- \text { и(ие) }\end{array}$ & 17 \\
\hline Suffixation /-б(a) & 14 & $1,17 \%$ & 4 & Suffixation /-б(a) & 14 \\
\hline Suffixation /-ин(a) & 13 & $1,08 \%$ & - & Suffixation /-ин(a) & 13 \\
\hline Suffixation /-есть & 9 & $0,75 \%$ & - & Suffixation /-есть & 9 \\
\hline Suffixation /-ов(ь) & 8 & $0,67 \%$ & 8 & Suffixation /-ов(ь) & 8 \\
\hline Suffixation /-ок & 8 & $0,67 \%$ & 1 & Suffixation /-ок & 8 \\
\hline /Suffixation -к(а) & 7 & $0,58 \%$ & 7 & /Suffixation -к(а) & 7 \\
\hline Suffixation /-иц(a) & 7 & $0,58 \%$ & - & Suffixation /-иц(a) & 7 \\
\hline $\begin{array}{l}\text { Suffixation /-ан(ье), } \\
\text { ен(ье) }\end{array}$ & 7 & $0,58 \%$ & 7 & $\begin{array}{l}\text { Suffixation /-ан(ье), } \\
\text { ен(ье) }\end{array}$ & 7 \\
\hline Suffixation /-еств(o) & 6 & $0,5 \%$ & - & Suffixation /-еств(o) & 6 \\
\hline Suffixation /-ищ(е) & 5 & $0,42 \%$ & 4 & Suffixation /-ищ(е) & 5 \\
\hline Suffixation /-ox & 5 & $0,42 \%$ & 3 & Suffixation /-ox & 5 \\
\hline Suffixation /-исть & 5 & $0,42 \%$ & 5 & Suffixation /-исть & 5 \\
\hline Suffixation /-еж-д(a) & 5 & $0,42 \%$ & 5 & Suffixation /-еж-д(a) & 5 \\
\hline Suffixation /-изн(a) & 4 & $0,33 \%$ & 1 & Suffixation /-изн(a) & 4 \\
\hline Suffixation /-ик(a) & 3 & $0,25 \%$ & 1 & Suffixation /-ик(a) & 3 \\
\hline Suffixation /-ев(a) & 2 & $0,17 \%$ & - & Suffixation /-ев(a) & 2 \\
\hline Suffixation /-ел(ь) & 2 & $0,17 \%$ & 2 & Suffixation /-ел(ь) & 2 \\
\hline Suffixation /-овн(я) & 1 & $0,08 \%$ & 1 & Suffixation /-овн(я) & 1 \\
\hline Suffixation /-ч(ея) & 1 & $0,08 \%$ & 1 & Suffixation /-ч(ея) & 1 \\
\hline Suffixation /-еч(ь) & 1 & $0,08 \%$ & - & Suffixation /-еч(ь) & 1 \\
\hline Suffixation /-ств(ие) & 1 & $0,08 \%$ & - & Suffixation /-ств(ие) & 1 \\
\hline Suffixation /-н-ость & 1 & $0,08 \%$ & - & Suffixation /-н-ость & 1 \\
\hline Prefixation /He- & 5 & $0,42 \%$ & - & Prefixation /Hе- & 5 \\
\hline Prefixation полу- & 8 & $0,66 \%$ & - & Prefixation полу- & 8 \\
\hline Prefixation $/ y-$ & 1 & $0,08 \%$ & - & \begin{tabular}{|l|} 
Prefixation /y- \\
\end{tabular} & 1 \\
\hline $\begin{array}{l}\text { Not motivated } \\
\text { foundation }\end{array}$ & 200 & $16,66 \%$ & - & $\begin{array}{l}\text { Not motivated } \\
\text { foundation }\end{array}$ & 200 \\
\hline On aggregate & 1,200 & $100 \%$ & 484 & On aggregate & 1,200 \\
\hline
\end{tabular}


In the process of problem's analyzing occasional cases of application of the following suffixation formants were registered: Russian e.g. еств (o), -ищ)(е), -ох, -исть, -изн(а), -ик(a), -ев(а), -ель, -овн(я), -ч(ея), -ечь, -ств(ие), -еж-д-, -н-ость. Their total number is just $3.5 \%$ (42 words). They were built on verbal and participle foundations (Russian e.g одиноче-ствоphysical state (loneliness); скоп-ище (gathering) - measure; ненав-исть, зав-исть, истер$u \kappa-a$, гор-ечь, над-ежд- $a$ - emotional state; желт-изн- $a$, голуб-изн- $a$, син-ев- $a$ - ознака; мист-ик- $a$ - subjective evaluation; гибель, болт-овн-я, тол-ч-ея, сумат-ох- $a$ - process; горяч-ность - (hot temper)-behaviour).

A high degree of productivity in abstract nouns, used by M. Bulgakov in the text of his novel have affixation-free method of derivation, also known as zero-affixation. Zero affixation in contemporary Russian (and also in Ukrainian) is used for coining of verbal and participle derivatives.

Nouns, that are structurally or semantically motivated by verbal foundations occupy a significant lexical mass among the grammar class of nouns, their peculiarity being in combination of some elements of verbal semantics with categorical meanings of noun.

The majority of affixation-free verbal abstract nouns of the Russian language were formed from the roots of prefixed verbs (Russian e.g. выход, отсев, разгром). There are much smaller formations from prefixed-free foundations (Russian e.g. зов, крик, стон). This is explained by the act that prefixation of verbal foundations stimulates their participation in derivation, according to the model of zero-affixation coining model, rather than by the fact that prefixation combinations prevail in the class of verbs.

All verbal suffixes are cast aside at zero-affixation building of verbal nouns, while zero-suffixation ensures transition of the verbal base into the class of words, that are capable of expressing abstract significance. In the word-building model of zero-affixation coining of abstract nouns, foundations of both perfective and non-perfective aspects function.

The words, built by the method affixation-free derivation (by means of zero affixation) represent quite a numerous group in our research. Numerically, they comprise 432 words, i.e. $36 \%$ of the total number of abstract nouns, found in the next of M. Bulgakov's novel. However, the bulk of them (106 words) were formed on participle foundation.

They may give the text of "Master and Margarita" novel greater expressiveness and emotional filling. It may be confirmed by the fact that $33.1 \%$ abstract nouns, built by means of zero-affixation method belong to the lexical-semantic group, expressing emotional and psychological state of man (Russian e.g. гнев, скука, досада). Also, $21.2 \%$ of words characterize process (Russian e.g. гул, рев, иум, грохот, бунт), $16 \%$ carry the meaning of subjective estimation (Russian e.g. правда, ложь, истина, вздор), while $14.1 \%$ characterize physical state of subjects or objects (Russian e.g. бессмертие, бессилие, беззвучие). The meaning of manifestation of attitude or perception of situation is typical of $7.6 \%$ (Russian e.g. uнтерес, восторг, зависть) of words, coined by the method of zero suffixation and $6 \%$ are nouns, denoting signs or properties (Russian e.g. тепло, холод, талант, память). Lexical-semantic groups, characterizing estimation of measure, circumstances and social signs occupy, entirely, just about $2 \%$ of the total number (Russian e.g. чащза, гущуа, несчастье, честь).

\section{Conclusions}

The greater part of nouns with abstract meaning, that we have analyzed were built by means of suffixation or zero-affixation methods, although in M. Bulgakov's novel abstract nouns, coined by prefixation method are also present. The share of words, formed by prefixation 
is $1.16 \%$. Prefixes act as formants for such method of derivation: Russian e.g. nолу-, не-, $y$ (рос. не-терпение, полу-сон, полу-мрак, пол.-бедьл, у-пор).

Despite the fact that suffixation ad affixation-free derivation prevail in the process of word building of the investigated words, words with non-motivated form quite a numerous group. In our research they number reach 200 words, i.e. $16.66 \%$ of the total number (Russian е.g. прах, судьба, смысл, суть, чепуха, страх, горе, мрак, тьма, талант, время, долг).

So, in the process of investigation the registered abstract nouns were divided into nine lexical and semantic groups: emotional and psychological state of man, process or action, objects of subjective estimation or attitude to situation, external or internal signs, estimations of degree or measure, circumstances or situations and also social estimations.

The biggest group are abstract nouns with the meaning of emotional and psychological state, their number being nearly one third of the total number of analyzed units. We can explain this fact because M. Bulgakov allocates a big part of his novel to description of inner state of his characters, their emotional experiences, emotions, soul seeking, and hesitating, as the entire work rests on the comparison of inner and outer, abstract and concrete.

As the analysis showed the level of nouns' abstractness correlates with the numerical data, the bigger the level of abstractness is, the bigger in size is the lexical-semantic group. Our derivational analysis demonstrated this regularity, as the greater part of abstract nouns in "Master and Margarita" novel, by M. Bulgakov were created by methods of suffixation and zero-affixation methods, the lexical units, belonging to "psychological and emotional state" and "process and action" group form the biggest share, while the smallest part belongs to the group, denoting estimation of measure and degree, manifestation of signs or degree of intensity of a process.

The text of M. Bulgakov's novel "Master and Margarita" is of unlimited interest not only for specialists of literature, but for linguists as well, so we belive that further investigations of this literary text in structural-semantic and translation study aspects seem to be have some good perspectives.

\section{References}

Bulgakov, M. (1989). Master i Margarita [Master and Margarita]. Kyiv: Dnipro. [in Russian] Leontev, A. A. (1965). Slovo v rechevoj deyatelnosti: nekotorye problemy obshhej teorii rechevoj deyatelnosti [Word in speech activity: Some problems of the general theory of speech activity]. Moscow: Nauka. [in Russian]

Lisichenko, L. A. (1977). Leksikologiya suchasnoï ukraïnskoï movi. semantichna struktura slova [Lexicology of the modern Ukrainian language. Semantic structure of words]. Kharkiv: Prohres. [in Ukrainian]

Polyuga, L. M. (1991). Ukraïnska abstraktna leksika XIV-XVI st. [Ukrainian abstract vocabulary of the XIV-XVI centuries]. Kyiv: Naukova dumka. [in Ukrainian]

Rusanivskij, V.M./Taranenko, V.O. (2000). "Ukraïnska mova”. Enciklopediya [Ukrainian language. Encyclopedia]. Kyiv: Naukova dumka. [in Ukrainian]

Shmelyov, D. N. (1973). Problemy semanticheskogo analiza leksiki [Problems of semantic analysis of vocabulary]. Moscow: Nauka. [in Russian]

Bloomfield, L. (1933). Language. N.-Y: Holt, Pinehart und Winston. [in English]

Lyons, J. (1969). Introduction to Theoretical Linguistics. Cambridge. [in English] 